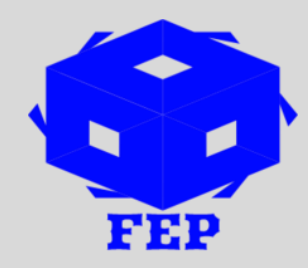

\title{
THE EFFECTS OF FIRM SIZE ON RISK AND RETURN IN THE BRAZILIAN STOCK MARKET: A SECTORAL ANALYSIS
}

Jessica Antunes ${ }^{1}$, Alexsandro Rodrigues Meireles ${ }^{2}$, Aline Sanfelici ${ }^{3}$, Rodrigo Garcia ${ }^{4}$ ${ }^{1,2,3,4}$ Braz Cubas University, Brazil

*Corresponding Author: Jessica Antunes

Article Received: 05-09-19
Accepted: 18-12-19
Published: $10-01-20$

Licensing Details: Author retains the right of this article. The article is distributed under the terms of the Creative Commons Attribution-Non Commercial 4.0 License (http://www.creativecommons.org/licences/by-nc/4.0/) which permits non-commercial use, reproduction and distribution of the work without further permission provided the original work is attributed as specified on the Journal open access page.

\begin{abstract}
The theory of capital market is to deal with the equilibrium relationship between risk and expected return on risky assets. Based on the theory, the present study investigates the effects of sectoral size (sectoral capitalization) on risk and expected return for the period of 20002004 as monthly. Multifactor model is utilized in the study using the Arbitrage Pricing Theory in analyzing the effects of sectoral size on the risk and return by utilizing the ordinary least square estimation procedure. The findings indicate that the firm size or sector have insignificant effects on firm or sectoral return in the Brazilian stock market.
\end{abstract}

Keywords: Risk, Return, Firm Size, Arbitrage Pricing Theory, Brazilian Stock Market.

\section{INTRODUCTION}

The Brazilian stock market is an emerging market as Brazil is part of the BRIC. Generally, investment in stock market is considered as a long term investment. Any human activity bring with it some degree of risk. Every investment brings with it some sort of risk. While making investment, it is important to take proactive measure to minimize the risk. Generally, in investment situation, the higher the risk, the higher the return (Menggen, 2007; Oludoyi, 2003; Adelagan, 2001). In stock market world, the common feature is the bull and bear feature which explains the expectations of stock price rise or drop (Okeke, 2008). Stock market is considered risky because there is always possibility of some risk. The stock market 
related risk and return may differ since different factors affect stock such as managerial capacity of firms, sector, size of the firm, government policies, and the structure. Literature indicate that a firm's return and risk depends on factors beyond organizational internal factors such as sensitivity to economy (Abdullahi, 2011; Girad \& Sinha, 2008). In present study, the sectoral analysis is conducted since each sector has its own requirements and influenced collectively by industry and country environment. In literature, most of the stock investment decisions taken by investors are done based on either the rule of the

\section{LITERATURE REVIEW}

Literature indicate that there are several factors influencing stock risk and returns. One study by Chen, Roll, \& Ross (1986) investigated the influence of macro-economic data series for explaining US stock return. The study variables included oil prices, consumption, inflation, risk premium market capitalization, and term structure of industrial production. The study results showed that these variables are predicting the expected return and the risk.

A study by Brown and Wein (1983) tested the APT in the context of bilinear paradigm introduced by Kruskal (1978). The study reported a 3 factor APT model and refuted the 5 or 7 factor model. The results indicate that few important factor in economy plays their role in shaping a firm's risk and return compare to the many factors as previously thought.

A study by Lehman \& Modest (1987) of all the decision choices, a model estimate is least effected by the number of factors. If the factors specified economic fundamental(s), one uses simple regression of factor providing security risk-return on the factor score, to estimate the factor loadings. This is applicable to this study.

\section{RESEARCH METHODOLOGY}

The study data is based on the sample of firms listed in the Brazilian stock exchange for the 2000 to 2004 time period on monthly basis. The data about the proxy for the sector size is obtained from the stock exchange as well. Ordinary least square method is used for estimation procedure.

\section{Table 1}

\begin{tabular}{clc}
\multicolumn{3}{l}{ Industry/Sector Classification } \\
\hline S/No & \multicolumn{1}{c}{ Sector } & Number of firms \\
\hline 1 & Agric & 2 \\
2 & Automobile \& Tyre & 2 \\
3 & Banking & 6 \\
4 & Building material & 2 \\
5 & Breweries & 2 \\
6 & Chemical paints & 4 \\
7 & Commercial services & 2 \\
\hline
\end{tabular}




\begin{tabular}{clc}
\hline 8 & Conglomerates & 3 \\
9 & Constructions & 2 \\
10 & Engineering & 2 \\
11 & Food/Beverages \& Tobacco & 4 \\
12 & Health & 4 \\
13 & Industrial Domestic Products & 4 \\
14 & Insurances & 7 \\
15 & Managed fund & 2 \\
16 & Packaging & 2 \\
17 & Petroleum (Marketing) & 3 \\
18 & Printing \& Publication & 3 \\
19 & Real Estate & 2 \\
20 & Textiles & 2 \\
& Total & \\
\hline
\end{tabular}

The data utilized in the study is monthly basis. Based on the guideline by Gunsel and Gukar (2007), lagged effects of capitalization on variables on stocks risk and return is expected. Since in stock exchange market, investors usually take decisions based on expectations and if expectations are realized, there is no unexpected change in the stock prices. The hypothesis only applicable to the efficient stock exchange markets. However, mostly, the stock exchange markets are inefficient and have time lag factor. The time lag is because of the fact that investors wait for the effects for a change.

\section{The Returns Model Specification}

The returns of firms' shares can be obtained using both share pricing and dividend as $\mathrm{R}_{\mathrm{jt}}=\underline{\mathrm{P}_{\mathrm{jt}}+\mathrm{D}_{\mathrm{jt}}-\mathrm{P}_{\mathrm{jt}-1}}$

Pjt-1

Where $\mathrm{R}_{\mathrm{jt}}=$ actual return on firm at period $\mathrm{t}$

$\mathrm{P}_{\mathrm{jt}}=$ Price of firm $\mathrm{j}$ at period $\mathrm{t}$

$\mathrm{P}_{\mathrm{jt}-1}=$ price of firm $\mathrm{j}$ at period $\mathrm{t}-1$

$D_{\mathrm{jt}}=$ dividend paid on each share of firm at period $\mathrm{t}$

If we take the natural $\log$ of the series we obtain returns in (1) above by subtracting in period $\mathrm{t}-1$ from those in period $\mathrm{t}$ plus dividend to arrive at:

$\mathrm{L}_{\mathrm{n}} \mathrm{R}_{\mathrm{jt}}=\mathrm{L}_{\mathrm{n}}\left(\mathrm{P}_{\mathrm{jt}}+\mathrm{D}_{\mathrm{jt}}-\mathrm{P}_{\mathrm{jt}-1}\right)-\mathrm{L}_{\mathrm{n}}\left(\mathrm{P}_{\mathrm{t}-1}\right)$

\section{Factor and Risk Model Specification}

The Arbitrage pricing theory propose numerous factors which have influence on a firm's risk and return thus it can be said that the theory is multifactor model based. The risk return asset is presented below. 


$$
R_{j}=b_{j o}+b_{j 1} F_{j 1}+\square j
$$

Where $R_{j}$ is the realized return on sectoral portfolio and $b_{j}$ is the reaction coefficient measuring the change in portfolio returns for a change in risk factor and $F_{j}$ is the size factor.

In this study the factor employed is size proxy by sectoral capitalization.

$\mathrm{Fj}=$ Sectoral capitalization

$\square=$ A residual error for sector portfolio

For identification of variables which have impact on stock market, ATP is proposed by Chen,

Roll and Ross (1986). For market portfolio, the risk of security is computed as follows;

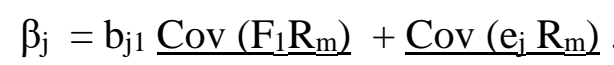

$$
\square 2 \mathrm{~m} \quad \square 2 \mathrm{~m}
$$

Where $B_{j}=$ risk of security

$b_{j 1}=$ the reaction coefficient measuring the change in portfolio risk

$\mathrm{Fi}=$ size of the sector

$\operatorname{Cov}\left(R_{j} R_{m}\right)=$ covariance of the firm $j$ with market portfolio.

$\square_{\mathrm{m}}^{2}=$ variance of the market return.

\section{RESULTS}

Table 2

\begin{tabular}{|c|c|c|c|c|c|}
\hline $\mathrm{S} / \mathrm{N}$ & Sector & Return \% & Risk & Capitalization & $\begin{array}{l}\text { Sectoral contribution to Stock } \\
\text { Exchange \% }\end{array}$ \\
\hline 1 & Agric & 22 & 0.99 & 10.36 billion & 0.45 \\
\hline 3 & Automobile \& Tyre & 4.9 & 0.91 & 3.6 billion & 0.05 \\
\hline 3 & Banking & 6.6 & 0.66 & 1963.9 billion & 61.5 \\
\hline 4 & Building material & 2.9 & 1.06 & 63.4 billion & 5.65 \\
\hline 5 & Breweries & 9.3 & 0.90 & 34.6 billion & 6.50 \\
\hline 6 & Chemical paints & 20.6 & 0.46 & 4.01 billion & 0.19 \\
\hline 6 & Commercial services & 2.9 & 0.06 & 100 million & 0.06 \\
\hline 9 & Conglomerates & 20.3 & 0.45 & 103.61 billion & 5.09 \\
\hline 9 & Constructions & 0.5 & 0.50 & 5.90 billion & 1.19 \\
\hline 10 & Engineering & 6.0 & 1.3 & 430.6 million & 0.14 \\
\hline 11 & $\begin{array}{r}\text { Food/Beverages } \\
\text { Tobacco }\end{array}$ & 9.6 & 0.93 & 343.1 billion & 9.9 \\
\hline 13 & Health & 4.6 & 0.43 & 14.0 billion & 0.55 \\
\hline 13 & $\begin{array}{l}\text { Industrial Domestic } \\
\text { Products }\end{array}$ & 5.9 & 0.36 & 5.99 billion & 0.56 \\
\hline 14 & Insurances & 6.3 & 0.51 & 39.94 billion & 4.66 \\
\hline 15 & Managed fund & 6.5 & 0.36 & 3.45 billion & 0.09 \\
\hline 16 & Packaging & 9.5 & 0.63 & 4.66 billion & 0.56 \\
\hline 16 & Petroleum (Marketing) & 20.3 & 0.60 & 340 billion & 6.46 \\
\hline
\end{tabular}

Sectoral Risks, Returns and Capitalization 


\begin{tabular}{llllll}
\hline 19 & Printing \& Publication & 6.0 & 0.60 & 939.6 million & 0.19 \\
19 & Real Estate & 11.3 & 0.93 & 9.63 billion & 0.33 \\
30 & Textiles & 4.9 & 1.03 & 3.9 billion & 0.03 \\
\hline
\end{tabular}

The results in table shows that in Brazilian stock market, the banking sector is dominating in terms of value of trading, market capitalization, and volume of trading. The banking sector contribution is about $61.2 \%$ to the total market capitalization whereas other sector contribution is about $38.8 \%$. The dominance of the banking sector in the market can be due to the government policy. Out of the sectors studied, almost half of the sectors have above average returns from the market return i.e. about $7 \%$. A low return is observed in the real estate sector but it has shown highest return. Same is the case of agricultural sector which have less contribution but the return is high. By comparing the results of the banking sector with the agriculture and the real estate, we can conclude that sector size does not have much influence on the sectoral return.

\section{Regression Results}

Table 3

Effects of Sector's Size on Sectoral Return

\begin{tabular}{lllll}
\hline Model & Coefficient & Standard errors & t-statistics & Prob. $t$ \\
\hline & & & & \\
(constant) & 0.068 & 0.0081 & 8.47 & 0.00 \\
Sector's size & 0.018 & 0.0033 & 1.57 & 0.59 \\
\hline
\end{tabular}

The coefficient for the sector size is 0.018 with the t-statistics of 1.57 and $p$ value of 0.59 which indicate that the sector size has insignificant influence on the sectoral return. The results of the study are matching with some other studies (e.g. Abdullahi, 2011; Lu \& Wang, 2009; Leung, 2000).

Table 4

Measure of the Model Strength

\begin{tabular}{llll}
\hline R-squared & S.E. of Reg. & S.D. of Dept. Var. & Durbin Watson \\
\hline 0.47 & 0.029 & 0.032 & 2.08 \\
\hline
\end{tabular}

The Rsquare value indicate that for the sectoral return, $47 \%$ changes are explainable by the sector size. The DW statistics is close to 2 so it shows that there is no problem of autocorrelation in our data. Conclusion

The regression results indicate that sectoral size tested has no significant influence on both sectoral risk and return. This indicates that other economic fundamentals affect the sectoral risk and return or the multi-factor APT model with sectoral size variable fails to explain the effect on sectoral risk and return. 


\section{CONCLUSION}

The objective of the study was to test the influence of sector size on the sectoral return. The findings of the study shows that in the Brazilian stock market context, the sector size does not have significant influence on the sectoral profit.

\section{References}

Abdullahi, I.B. (2011). Sectoral Analysis of Risks and Returns of the Quoted Firms in the Nigerian Capital Market (Unpublished Ph.D.) Thesis Submitted to University of Ilorin, Nigeria.

Adelegan, O.J. (2001). The Cost of Capital and Return on Investment Conglomerates in Nigeria: 1984-1999, $4^{\text {th }}$ Annual Conference of the Centre for study of African Economies between March $29^{\text {th }}$ and $3^{\text {rd }}, 2009$ at University of Oxford pp.22-31.

Ahmed, S. (2008). Aggregate Economic Variables and Stock market in India. International Research Journal of Finance and Economics, 14, 141-65.

Barry, C.B. (2002). Robustness of Size and Value Effects in Emerging Equity Markets. Emerging Market Review, 3, 1-30.

Benz, W. (2002). The Value and Size Effect: Are These Firm-Specific Risks in China's Domestic Stock Market? Journal of Financial Economic, 7, 15-40.

Brown, S.J., \& Weinstein, M.I. (1983). A New Approach to Testing Asset Pricing Models: The Bilinear Paradigm. Journal of Finance, 38, 22- 39.

Campbell, R.A. (1995). The Risk Exposure of Emerging Equity Market. The World Bank Economic Review, 9(1), 29-50.

Chen, N.F. (1991). Financial Investment Opportunities, and the Macro Economy. Journal of Finance 46(1), 529-583.

Chen, R., \& Ross. (1986). Economic Forces and the Stock Market. Journal of Business 39(3), 383-403.

Dickinson, D.G. (2000). Stock Market Integration and Macro-Economic Fundamentals and Empirical Analysis. Applied Financial Economics, 10, 261-76.

Fama, E. (1990). Stock Returns, Expected Returns and Real Activity. Journal of Finance, 45(1), 108-118.

Fan, K., Lu, Z. \& Wang, S. (2009). Dynamic Linkages between the China and International Stock Markets. Asia-Pacific Financial Markets, 16, 211-30.

Fernald, J.G., \& Rogers, J.H. (2002). Puzzles in the Chinese Stock Market. Review of Economics and Statistics, 84, 416-432.

Funga, H.G., Lee, W., \& Leung, W.K. (2000). Segmentation of A-and B- Share Chinese equity Markets. Journal of Financial Research, 23, 179-195.

Girad, E., \& Sinha, A. (2008). Risk and Return in the next Frontier. Journal of Emerging Market Finance, 7, 43-80.

Goviaev, A. (2004). Risk Factors in the Russian Stock Market. Emerging Market Review 2(1), 67-89.

Gunsel, N., \& Cukur, S. (2007). The Effect of Macro Economic Factors on the London Stock Returns: A Sectoral Approach. International Research Journal of Finance and Economics, 10,140-52. 
Jonathan, W., \& Lovie, Z. (2007). Estimating and Comparing the Implied Cost of Equity for Canadian and US Firms, Bank of Canada Working Paper, pp.48-62.

Lehman, J., \& Modest, V. (1987). Arbitrage Pricing Theory. Working Paper, pp.1-24.

Leon, K. (2008). The Effect of Interest Rate, Volatility on Stock Returns and Volatility: Evidence from Korea International Research Journal of Finance and Economics, 14, 285-90.

Mans, K. (2007). The Empirical Relationship between Firm Level Investments, Stock Return, Systematic Risk and the Book-to-Market Effect. Journal of Finance, 61, 171-194.

Menggen, C. (2007). The Risk-Return Trade off in Emerging Stock Market: Evidence from China. Seminar Paper Presented at ARRC Auditorium, A/RC/014. Hosted by Department of Economic and Related Studies (DERS) Wed. 20 ${ }^{\text {th }}$ June 2007 Peking University.

Nassel, A., \& Strauss. (2000). Stock Prizes and Domestic and International Macro Economic Activity: A Cointegration Approach. The Quarterly Review of Economics and Finance, 40, 229-45.

Nikolaos, S., Girigoris, G., Nikolaos, L., \& Nikos, K. (2009). Empirical Analysis of Determinants of D.J.S.I. US Mean Returns. World Academy of Science, Engineering and Technology, 54, 96-108.

Okeke, M. (2008). Markets, Risk and Reward. Zenith Economic Quarterly, 208, 2.

Oludoyi, S.B. (1998). Capital Market Efficiency and The Effects of Earnings Announcement on Share Prices in Nigerian (Unpublished Ph.D. Thesis), Dept. of Economics, University of Ibadan, Nigeria.

Oludoyi, S.B. (2003). An Empirical Analysis of Risk Profile of Quoted Firms in the Nigerian Stock Market. Ilorin Journal of Business and Social Sciences, 8(1\&2), 9-19.

Roll, R., \& Ross, S.A. (1980). An Empirical Investigation of the Arbitrage Pricing Theory. The Journal of Finance 3(5), 1073-1103.

Ross, S. (1993). Is beta Useful? In the CAPM Controversy: Policy and Strategy Implication for Investment Management, ICFA Continuing Education. IN D.R. Harrington \& R.A. Korajezyk (eds) New York AIMR.

Serra, A.P. (2007). The Cross-Sectional Determinants of Returns: Evidence from Emerging Market's Stocks Working Papers da FEP No.120 December, 2002.

Shanken, J., \& Weinstein, M.I. (2006), Economic Forces and Stock Market Revisited. Journal of Empirical Finance, 13,129-44.

Sharpe, W.F. (1964). Capital Asset Prices: A Theory of Market Equilibrium under Conditions of Risk. Journal of Finance, 18, 424-447.

Sunitas, A., \& Kenourgios, D. (2007). Macro-Economic Factors' Influence on new European Countries Stock Return: The Case of Four Transition Economies. International Journal of Financial Services Management, 2, 34-49. 